\title{
THE NOTION OF POLITICS IN MARX'S EARLY WRITINGS
}

\author{
Humberto SchetTino* \\ Political Science Department \\ Rutgers University \\ hschettino@yahoo.com
}

SUMMARY: This paper deals mainly with Marx's conception of politics. My contention is that in Marx's works two basic and opposed conceptions of politics coexist. On the one hand we find a negative, instrumental and realist conception that sees politics as nothing but domination of one class over another and the State as the main instrument of that domination. On the other, we find a positive conception that understands politics as community self-rule. I trace the conceptual origins of these two conceptions to three basic concepts: "alienation", "emancipation" and "species-being". These notions provide the foundations of Marx's conception of politics and enable us to understand its shortcomings. It is basically a contradictory and utopian conception which seriously disregards both the positive traits of actual politics and individual freedoms.

KEY WORDS: alienation, emancipation, species-being, community

RESUMEN: El tema central de este trabajo es la concepción de la política de Marx. En el artículo sostengo que es posible encontrar dos concepciones básicas de la política en los escritos de Marx: por un lado, una concepción negativa, instrumental y realista que la concibe como la dominación de una clase sobre otra, y al Estado como el instrumento principal de tal dominación; por el otro, una concepción positiva que entiende la política como el autogobierno de una comunidad. Estas concepciones están basadas en tres conceptos fundamentales de la obra de Marx: "enajenación", "emancipación" y "ser de la especie", los cuales nos permiten entender los errores de la concepción general de la política de Marx. Se trata de una concepción contradictoria y utópica, que no entiende ni las características positivas de la política efectiva, ni la importancia de las libertades individuales.

PALABRAS CLAVE: enajenación, emancipación, ser de la especie, comunidad

*Adjunct Professor of Political Theory. 
German criticism has $[\ldots]$ never quitted the realm of philosophy.

GI, p. 148

Only in socialism can a philosophical people find its corresponding praxis, which is to say, only in the proletariat can it find the active element of its liberation.

CNKP, p. 110

\section{Introduction}

Marx is regarded by almost any expert as one of the classics of political thought. Both defenders and critics consider Marx's contributions to the understanding of politics to be as important as his writings on history, society and economics. By the same token, some version of Marxism has, for more than 150 years, served as guide or inspiration for radical political action. It is surprising, therefore, that the concept of politics in Marx's writings has received little attention in contrast with the astonishing amount of analysis, interpretation, reconstruction, criticism, to which every other aspect of his thought has been subjected.

This statement would seem to be simply wrong on two counts. On the one hand, there is a vast amount of commentary devoted for years to the problems of revolution, the communist party, and/or Marx's criticism of the State, of bourgeois rights and of formal democracy. So it would appear that the notion of politics in Marx's thought is well covered by commentators. On the other hand, politics was abandoned by the young Marx as the correct way to achieve emancipation, and the concept of politics has only a minor role in his thought after the Manifesto of the Communist Party (1848; MCP), so it would appear that, after all, it is not an important notion in his work. Thus, politics for Marx (and Marxists) would seem to be both not that important and pretty well covered by the legions of commentators.

In this paper I will maintain that this is not the case. The accepted general interpretation of Marx's conception of politics as an epiphenomenon or an instrument of the powerful is only part of the story. There is another, "positive", conception of politics in the writings of the young Marx, built around a peculiar conception of "democracy". The positive conception of 
democracy has had great influence on actual left-wing politics worldwide. It has given social critics and radicals the model or, at least, the image of a just society and, equally importantly, it has given them a conception of what politics truly is: the mindful and responsible participation of all citizens in public affairs, which means self-rule and which in turn means the cancellation of rule on Marx's view. ${ }^{l}$ This is consistent with actual political practice of the radical left worldwide, usually guided by a conception of politics and democracy that combines lofty values - emancipation, human liberation and accomplishment - with the utopian project of a society without domination.

Marx's use of both conceptions resulted in an odd combination that has had lasting - and confusing - effects on radical left-wing thought. As we shall see, one of these renders a dark and realist (although simplistic) conception of politics as pure domination, whilst the other yields a lofty and hopeful (if not utopian) conception of democracy as the solution to "the riddle" of all constitutions. Politics, then, is both bad and good, and the decisive distinguishing criterion is the presence or absence of domination.

The serious scholar might say that all this has already been said. After all, isn't it well known that Marx had a negative conception of politics? Or that Marx's utopian project offered precisely the cancellation of domination? The answer is both yes and no. On the one hand, the general elements of Marx's arguments on the subject are well-known; but, on the other, the assumptions and overall content of his conception of politics, the reasons for the abandonment of politics as an object of study and as a domain of effective emancipation, and the consequences of his inconsistent views on politics have not been fully analyzed or ascertained.

In this paper it is my contention that Marx's overall conception of politics is the result of the combination of two different notions: "power" and "community" politics. I trace the basic assumptions of this conception in Marx's early writings

\footnotetext{
${ }^{1}$ Since the final objective of Marx's argument is to cancel all domination (all "rule").
} 
- the concepts of "alienation" and "emancipation" and the notion of "species-being" - and show that Marx's positive conception is - using his own categories - basically an idealistic conception, dependent on unwarranted philosophical assumptions, and which due to this reliance upon philosophy, has had extremely harmful consequences for contemporary politics. Finally, I point out the negative consequences of such a conception in three areas: the correct understanding of politics, democracy, and freedom.

Before dealing with these problems, one must ask a general question posed recently by Ian Shapiro (2003, Chap. 4): why bother with Marx's conception of politics? His policy and practical proposals have been completely discredited after the fall of the Soviet regimes. His predictions proved wrong. We hear many horror stories about the former Soviet regimes and about existing regimes that claim Marx's thought as their justification and ideological basis. Why bother with Marx, then? There are two main reasons. One, pointed out by Shapiro, is the great influence Marx had on the social and political thought of the nineteenth and twentieth centuries. The other is the enormous influence Marx's criticism of actual politics, as well as his ideal positive conception, still have in the "collective imaginary" of the left, on the efforts of many people involved in radical causes such as the fight against globalization, the defense of minority rights, the efforts to protect the poor, etc. What is the image of politics that organizes and directs their actions? What if it is wrong? Do they understand the consequences of their core conception of politics?

This does not mean that those (and many other) fights are not worth fighting, or that values such as justice and equality are not worth defending. On the contrary, what I want to examine here are the consequences, precisely for left-wing politics, of a concept that combines a utopian and a crudely realist understanding of what politics is, how it functions and what it can achieve.

There are procedures of politics that have proven successful through the years in achieving safe and stable societies, such 
as endless negotiations, prudence, respect for the law and for basic human rights, or careful consideration of the means as well as of the ends. The rejection of these has rendered most of radical politics - in spite of the relevance of some of its objectives - largely ineffectual. This is particularly significant in an age increasingly dominated by the ideology and politics of the right, that is, by inequality, authoritarianism, lack of respect for human rights and dignity, and a dangerous increase of the influence of religious values and organization on public life. The radical left has failed to win the support of majorities in industrialized countries due in part to its rejection of politics and it is my contention that this rejection of politics has its intelectual origins in Marx's two concepts of politics. We need to develop, once again, an anti-utopian and a realist (sophisticated) left. This paper hopes to offer a step in that direction.

\section{Marx's Negative Conception of Politics}

It is well known that Marx had a negative and instrumental conception of politics. It is usually recognized, also, that for Marx politics is an epiphenomenon of economic conditions and, therefore, just a way of masquerading economic interests and power. On this view, then, politics is nothing but one of the many ways capitalists have of dominating those who do not own means of production, and so politics has no value in itself and is useful only as one of the means of toppling the capitalist regime. This is why Marx took politics to be mainly a negative and instrumental activity. ${ }^{2}$

\subsection{Marx's Negative Conception of Politics. The Traditional View}

In his well-known introduction to Marx's thought, Jon Elster clearly described the "standard" construal of how Marx conceived politics. According to Elster:

\footnotetext{
${ }^{2}$ The exception being revolution. However, as revolution, politics is useful only in a derivative and provisional sense.
} 
There are two perspectives on politics in Marx's writings. On the one hand, politics is part of the superstructure and hence of the forces that oppose social change. The political system stabilizes the dominant economic relations. On the other hand, politics is a medium for revolution and hence for social change. New relations of production are ushered in by political struggles. To see the relation between the two functions of politics, they must be seen in the wider context of historical materialism. (Elster 1986, p. 141)

On the standard construal, then, politics is both part of the superstructure and an instrument, among others, for social change. Politics is, thus, both a byproduct of economic forces and an instrument to change those forces. In the words of another scholar of Marxist thought:

In the Marxist-Leninist structure of ideas politics had no autonomy. It derived from economic interests. It was, moreover, an increasingly futile business, since the further a mode of production developed the more acute the antagonism between dominant and subordinate classes became, and the more obvious the irreconcilability of their interests. Politics would increasingly become a dialogue of the deaf. (Harding 1992, p. 159)

This does not mean that the "Marxist-Leninist tradition" did not find a place for politics: "politics was always class politics" (Harding 1992, p. 159). Political action was, again, an instrument for raising the consciousness of the proletariat and for helping them to obtain power, in order to cancel out both politics and the State.

Marx is often thought to offer two distinct theories of the state in exploitative, class-divided societies. In the first conception, he saw it as an alien body over and above society [...]. In the second, he interpreted it primarily as the servant of a ruling class against workers, peasants, and other oppressed groups. (Gilbert 1991, pp. 173-174) 
It is this conception of the State and of politics as nothing more than instances of naked domination - concerning which any attempt at justification is nothing more than ideologythat has prompted some analysts to place Marx in the list of "realist" political thinkers. ${ }^{3}$

Hence, we can find two versions of the negative conception of politics in Marx's writings. The first one, following the most simplistic realist conception of politics, conceives politics as nothing more than the exercise of power and domination in a social environment divided into classes. There are, then, dominant and dominated classes, and politics is nothing other than the exercise of (political) power in favor of the dominant classes through any means conceivable, from law to naked violence.

There is another instrumental and residual conception of politics in Marx's writings: the revolutionary conception, i.e., a conception that construes politics as one of the instruments of the revolutionary class to supersede (or sublate) ${ }^{4}$ the political state. It should be clear that the usefulness of revolutionary politics, for Marx, is limited to the achievement of its main objective: the cancellation of capitalism, the State and politics itself.

These two conceptions of politics share three characteristics: they yield, in general, a negative, instrumental and realist view of politics. 5 The view is negative because there is no recognition of any positive dimension for politics, such as the achievement of order, the construction of social identities, or the capacity to unite diverse social forces into social power. It is instrumental, because politics is construed as an instrument (a medium) for the attainment of some objective, which can be either domination or emancipation. It is realist because Marx conceives politics, in its basic form, as nothing more than

\footnotetext{
${ }^{3}$ See, for instance, Bobbio 1976, p. 62.

${ }^{4}$ Both terms are commonly used to render in English the technical German term of "Aufhebung". I will be using both to mean the latter.

${ }^{5} \mathrm{I}$ am following here the analysis of Marx's political thought provided by Bobbio (1976).
} 
domination through force. ${ }^{6}$ This, however, is a simplistic and vulgar version of political realism. As Allan Megill has recently maintained, for Marx "politics is basically a bad thing" (Megill 2002, p. 58).

In the next section, I intend to show in a different way that Marx held a conception of politics that is mainly realist, instrumentalist and negative, by showing that it is determined by one philosophical concept ("alienation"), one ethical-political value ("emancipation"), and a particular conception of the human condition (as "species-being"). This general conception of politics, as we shall see, has as its source and counterpart a positive conception, which regards politics basically as community and self-government, that is, as participation in public affairs by everyone concerned, without vertical domination.

2.2. Marx's Negative Conception of Politics. The Assumptions

Marx presents his criticism of politics as a critique of the ideas presented by Hegel in his Philosophy of Right. The basic elements of this criticism are:

(1) the rejection of mediation,

(2) the use of three dichotomies: real/abstract, particular/universal, and materialism/idealism,

(3) the use of alienation as the basic concept of criticism, and

(4) the proposal of emancipation as the objective of theoretical and practical struggles of mankind.

In order to understand Marx's criticism of politics, it is necessary to consider, first, his Economic and Philosophical Manuscripts (henceforth EPM) of 1844. Of course, the reconstruction of Marx's thought I offer here does not coincide with

\footnotetext{
${ }^{6}$ Bobbio has pointed out that Marx has a realist and instrumentalist conception of the State. I am concerned with the concept of politics, not with that of the State, but the arguments are of course similar. See Bobbio 1976, p. 62 .
} 
its historical development; however, what interests me is a theoretical, rather than historical, analysis of Marx's ideas concerning politics.

In the EPM, Marx made a crucial distinction between objectification and alienation:

The product of labor is labor embodied and made material in an object, it is the objectification of labor. The realization of labor is its objectification. In the sphere of political economy this realization of labor appears as a loss of reality for the worker, objectification as loss of and bondage to the object, and appropriation as estrangement, as alienation [Entäusserung]. (EPM, p. 324)

So although political economy, whose principle is labor, appears to recognize man, it is in fact nothing more than the denial of man carried through to its logical conclusion: for man himself no longer stands in a relation of external tension to the external essence of private property - he himself has become the tense essence of private property. What was formerly being-external-to oneself, man's material externalization, has now become the act of alienation, i.e., alienation through selling. (EPM, p. 342, emphasis added.)

Marx's diagnosis and critique of the condition of the modern worker is presented through the concept of alienation. As the quotations show, a natural human process - objectification-, the process through which human beings produce the material conditions of their life, ${ }^{7}$ is transformed into a process in which those products become separated from human beings. Alienation reaches its paradigmatic form in capitalism through the fetishism of the commodity, but it is present everywhere a human product (be it religion, or the State) is separated from, and opposed to, the producer. Marx described alienation thus:

The externalization [Entäusserung] of the worker in his product means not only that this labor becomes an object, an external existence, but that it exists outside him, independently of him

${ }^{7}$ See EPM, p. 325. 
and alien to him, and begins to confront him as an autonomous power; that the life which he has bestowed on the object confronts him as hostile and alien. ${ }^{8}$ (EPM, p. 324)

How does Marx justify his notion of alienation, which is central for his discussion and critique of modern capitalism and politics in general? The notion that provides the basis for the Marxian concept of alienation is the ontological —as opposed to a merely anthropological- conception of man as a "species-being" (Marx's expression). ${ }^{9}$ This conception of man as a "species-being" provides Marx not only with the basis of his conception of alienation, but also with a normative criterion upon which he can judge any kind of society. The importance of this notion in Marx's thought cannot be underestimated, even if it does not appear to have a great role in his mature work.

Marx used the concept of "species-being" to refer to a specific process: the process through which human beings take the human and every other "species" (i.e., everything else in the world, including things and organisms) as their "object". In other words, Marx refers to the process through which human beings take other human beings and everything else as a means for their reproduction and, in doing so, transform both other human beings and every other thing into human, i.e., social "beings". To say, then, that human beings are "speciesbeing" means that (1) they are in a constant relation with other human beings and with organic and inorganic nature, (2) human

${ }^{8}$ Another version of the same theme is: "The devaluation of the human world grows in direct proportion to the increase in value of the world of things. Labor not only produces commodities; it also produces itself and the workers as a commodity and it does so in the same proportion in which it produces commodities in general" (EPM, pp. 323-324).

9 "If man's feelings, passions, etc., are not merely anthropological characteristics in the narrower sense, but are truly ontological affirmations of his essence (nature)" (EPM, p. 375). The quotation is incomplete, but it clearly shows Marx's distinction between anthropological and ontological conceptions of man. 
beings can reproduce only within these relations, and (3) in these relations the objects (human, organic, or inorganic), as well as the subjects, determine each other. ${ }^{10}$

The point Marx tried to elucidate is that there is an original union in the human condition between human beings and both other human beings and the rest of the "world". ${ }^{11}$ For Marx human beings "look upon" themselves as "universal and therefore free being[s]" (EPM, p. 327). Only in this direct and universal relationship, provided there is consciousness of it, human beings could be free, i.e., could achieve a perfect unity between the self, society, and nature. ${ }^{12}$ It is here where Marx's rejection of mediation appears in its most basic form (this is also evident in his treatment of the State and of politics).

The nexus between the concept of "species-being" and the notion of alienation is described by Marx in the following paragraph:

Estranged labor therefore turns man's species-being — both nature and his intellectual species-powers - into a being alien to him and a means of his individual existence. It estranges man from his own body, from nature as it exists outside him, from his

${ }^{10}$ As Allen Wood maintains, discussing Feuerbach's and Marx's use of "species-being": "The main intention of both philosophers in using the term, in fact, seems to be to imply that there is some sort of intimate connection between each man or woman and all other human individuals, and that the source of this connection is the fact that the qualities which constitute the essence of each individual are somehow bound up with those which are essential to the whole species, considered as a single collective being" (Wood 1981, p. 17).

${ }^{11}$ Again, Allen Wood makes clear this point: The "most obvious thing" they [Marx and Engels] mean [referring to "species-being"] "is that human beings live in societies, and the mode of life of each individual is essentially dependent on interaction or intercourse with others" (Wood 1981, p. 18).

12 "Man appropriates his integral essence in an integral way, a total man. All his human relations to the world — seeing, hearing, smelling, tasting, feeling, thinking, contemplating, sensing, directly communal in form, are in their objective approach or in their approach to the object, the appropriation of that object. This appropriation of human reality, their approach to the object, is the confirmation of human reality" (EPM, p. 351). 
spiritual essence [Wesen], his human essence. [...] An immediate consequence of man's estrangement from the product of his labor, his life activity, his species-being, is the estrangement of man from man. [...] In general, the proposition that man is estranged from his species-being means that each man is estranged from the other and that all are estranged from man's essence. (EPM, pp. 329-330)

What alienation breaks is the unity both within the self and in its "external" relations and, in doing so, it tears down the possibilities of the "total man", hence, of freedom. Of course, it could be argued that there is a basic anachronism in this approach — that it is flawed from the beginning - since the EPM were written after the Critique of Hegel's Doctrine of the State (henceforth CHDS) and consequently Marx could not have used the findings of the EPM as a framework. One reply to this possible objection would be to show how, even if they were not fully and explicitly used by Marx, the concepts of "alienation", "species-being", and "emancipation" can be discovered under the criticism of Hegel's political philosophy. We, therefore, need to look at Marx's criticism of Hegel's political philosophy.

\subsection{Philosophy and the Criticism of Politics}

Marx defined his own philosophical position against the background of Hegel's philosophy. For Marx, Hegel had identified the "Idea" of the State with the existing State and, even if Hegel's description - of the modern State - was accurate, the identification with the Idea was a mistake, in particular for two reasons: (1) it accepted the separation between State and civil society, and (2) it lacked the criticism of this "reality".

Marx's Critique of Hegel's Doctrine of the State is a very important text for understanding his reasons for a negative and instrumental conception of politics and, also, as a source of his view of democracy as an antecedent to the notion of communism. The main object is the criticism of Hegel's so-called "idealism". This "idealism" consisted in granting the "Idea" the 
place of the subject, ${ }^{13}$ instead of making the real human being the starting point of the theory. ${ }^{14}$ According to Marx, this idealism, again, has two consequences: the uncritical sanction of reality and, resulting from this, the description of civil society and state as separate. Marx stated his criticism of Hegel in the following passage:

Hegel should not be blamed for describing the essence of the modern state as it is, but for identifying what is with the essence of the state. That the rational is real is contradicted by the irrational reality which at every point shows itself to be the opposite of what it asserts, and to assert the opposite of what is. (CHDS, p. 127; MEGA, I.2, p. 68)

Marx's criticism is difficult to unravel. He makes it clear that he agrees with Hegel's description of the modern state, but he believes that this description does not conform to the "rational Idea" or, in other words, that it is an "irrational reality". Two questions come to mind. First, according to what criterion is it irrational? Second, what is it that makes reality irrational (i.e., which are the processes that determine its irrationality)? The basis of Marx's criticism can be found in the separation of civil society and the State, and in the opposition between universal and particular interests.

13 "Hegel [...] talks here [Philosophy of Right $\S 269]$ of the Idea as of a subject that becomes differentiated into its members. Apart from the reversal of subject and predicate, the appearance is created that there is an idea over and above the organism. The starting-point is the abstract Idea which then develops into the political constitution of the state. We are not concerned with a political Idea but with the abstract idea in a political form [...]. Hegel's sole concern is simply to rediscover 'the Idea', the 'logical Idea', in every sphere, whether it be the state or nature, whereas the real subjects, in this case the 'political constitution' are reduced to mere names of the Idea so that we are left with no more than the appearances of true knowledge. They are and remain uncomprehended because their specific nature has not been grasped" (CHDS, pp. 66-67).

14 "The crux of the matter is that Hegel everywhere makes the Idea into the subject, while the genuine, real subject, such as 'political sentiment', is turned into the predicate. The development, however, always takes place on the side of the predicate" (CHDS, p. 65). 
Hegel's starting-point is the separation of the 'state' from 'civil society', of particular interests' from the 'absolutely universal interest of the state proper', and it is perfectly true that the bureaucracy is based on this separation. (CHDS, p. 106; MEGA, I.2, p. 49)

As we can see, the basic topic of the EPM, i.e., alienation caused by the separation of human beings from his products and from other human beings (the devaluation, so to speak, of its species-being), appears in the political domain in the form of the separation of civil society and the state. Hegel's main point was that the private interest of the individual members of civil society would become a universal interest in the sphere of the State, through the action of the "Estates" and of "Bureaucracy". ${ }^{15}$ What Marx criticized was both the acceptance of the separation and the practical solution offered by Hegel.

Marx's treatment of politics in CHDS is organized through what later were to become the central tenets of his criticism. The problem with the modern state is that it separates the life of the individual into at least two different domains; the citizen, says Marx, "must [...] divide up his own essence" (CHDS, p. 143). This division of human essence, produced through the erection of an alien domain - the State-, proper of the modern age, clearly destroys what later will be called in the EPM "species-being". This very division facilitates the development of private interests, and makes it impossible to supersede them. In other words, human beings will not be able to attain the universality of interests as long as two separated domains of social life exist: civil society and the State. It is in the last part of the CHDS, reviewing Hegel's conception of the right to primogeniture, that Marx introduces what would later become the basic subject of his research: the direct connection, in the modern world, between private property and alienation.

The 'inalienability' of private property implies the 'alienability' of the universal freedom of the will and of ethical life. Property

${ }^{15}$ See Hegel, Philosophy of Right, $\S ~ 288,289$ and 302, for example. 
is no longer mine in so far as ' $\mathrm{I}$ put my will into it'; it is truer to say that my will only exists 'in so far as it exists in the property'. My will does not possess, it is possessed. (CHDS, p. 169)

In the political domain, this connection provided the basis for an early identification of the State with class interests, which later would become a characteristic trait of Marx's conception of politics:

The political constitution at its highest point is thus the constitution of private property. The loftiest political principles are the principles of private property [...]. Because such property is inalienable, the nerves connecting it to society are severed and its isolation from civil society is assured [...]. Whereas according to Hegel primogeniture represents the power of the political state over private property, it is in fact the power of abstract private property over the political state. (CHDS, pp. 166-167)

From this point onwards, Marx's way of dealing with politics changes. The result of his critique of Hegel's positions was twofold: (1) his conviction that the separation of politics and civil society would make it impossible to overcome alienation, and (2) his acknowledgement that the relevant critique has to take place in the domain of economics, against private property, and not in the domain of politics. This can be seen in the treatment of politics present in the other texts written during the 1840 's. We turn to them in the next section.

2.4. The Irrelevance of Politics. Alienation and Emancipation

The basic texts for understanding this stage of Marx's criticism of politics are the articles "On the Jewish Question" (1843; JQ), the "Introduction to the Critique of Hegel"s Philosophy of Right" (1843-1844; ICH), and volume I of The German Ideology (1845-1846; GI). In an historical sequence, the main themes of the critique of politics are: (1) the idea that political emancipation is not complete human emancipation, (2) the proposal of the proletariat as the universal class capable of overcoming alienation and (3) the proposal of the communist society. 
Throughout these themes one finds particular conceptions of the State that conform the negative, instrumentalist, and realist conception referred to in the first section of this paper. The basic point of Marx's conception of politics is its utter irrelevance in view of the basic objective of his social project: emancipation.

The first of the three themes presented before is developed at length in JQ. As is widely known, Marx sets himself to criticize a book by Bruno Bauer on the political emancipation of Jews and ends up criticizing the whole notion - and the real process - of "political emancipation" as incomplete. Political emancipation from religion, i.e., the separation of church and State, and the universal granting of political rights, regardless of religious confession is, Marx admits, an improvement of conditions (JQ, p. 221). Nevertheless, "political emancipation is not the complete and consistent form of human emancipation". It is clear, as we shall see, that at this stage of Marx's theoretical development, politics (and the basic political institution of modernity, the State) has only a minor role and is irrelevant for the attainment of liberation (i.e., the negative conception of politics is already present). But, why is it not possible to achieve emancipation through politics? This question finds a direct answer in the last paragraph of JQ, part I:

All emancipation is reduction of the human world and of relationships to man himself. Political emancipation is the reduction of man on the one hand to the member of civil society, the egoistic, independent individual, and on the other to the citizen, the moral person. ${ }^{16}$

Only when real, individual man resumes the abstract citizen into himself and as an individual man has become a speciesbeing in his empirical life, his individual work and his individual relationships, only when man has recognized and organized his forces propres as social forces so that social force is no longer separated from him in the form of political force, only then will human emancipation be completed. (JQ, p. 234; MEGA, I.2, pp. 162-163)

${ }^{16}$ In other words, it produces a separated human being. 
The importance of this paragraph justifies quoting it at length. Here Marx introduces the notion of "species-being" as the basic element for understanding emancipation, a subject that he will develop - as we have seen - in the EPM. Emancipation, the overcoming of the separation within human beings, and in their relation to "the world", the disappearance of any mediation, ${ }^{17}$ cannot be attained through politics because the domain of politics is the domain of separation par excellence. Political emancipation from religion takes place through a "medium" (JQ, p. 218), the State, and precisely the overcoming of any "medium" is what emancipation is all about. In JQ, Marx wrote one of the clearest paragraphs on the philosophical basis of his criticism of politics:

Man emancipates himself politically from religion by banishing it from the province of public law to that of private law. It is no longer the spirit of the state where man behaves $[\ldots]$ as a species-being, in community with other men. It has become the spirit of civil society, the sphere of egoism and of the bellum omnium contra omnes. It is no longer the essence of community but the essence of difference. It has become the expression of the separation, of man from his community, from himself and from other men, which is what it was originally. It is now only the abstract confession of an individual oddity, of a private whim, a caprice. (JQ, p. 221; MEGA, I.2, p. 150)

Politics, simply stated, is irrelevant, since the object is full human emancipation. It is, of course, a necessary moment but only in a derivative and instrumental capacity.

I will turn now my attention, finally, to two other writings that complete Marx's general conception of politics: The German Ideology (GI) and the Manifesto of the Communist Party (MCP). In both texts, the "devaluation" of politics is clear; politics is presented only as an instrument, even if it has some role to play as "revolutionary politics" (in MCP).

Marx ended GI describing the proletariat as having the need to "overthrow the State" (p. 200). This is a result of the radical

${ }^{17}$ This will be clear in Marx's descriptions of communist society. 
opposition between the class with "radical chains" and the "collective expression of the individuals, of which society consists" (GI, p. 200). We know that every time Marx uses "individuals", he is referring to "bourgeois individuals", alienated members of civil society that have constructed the State as an alienated expression of themselves. Just as "the ideas of the ruling class are in every epoch the ruling ideas" (GI, p. 170), and these ideas are "nothing more than the ideal expression of the dominant material relationships" (loc. cit.), so the State is "nothing more" than the expression of those "dominant material relationships". In the same text, GI, Marx presented this conception of the State:

Through the emancipation of private property from the community, the State has become a separate entity, besides and outside civil society; but it is nothing more than the form of organization which the bourgeois necessarily adopt both for internal and external purposes, for the mutual guarantee of their property and interests. [...] Since the State is the form in which the individuals of a ruling class assert their common interests, and in which the whole civil society of an epoch is epitomized, if follows that the State mediates in the formation of all common institutions and that the institutions receive a political form. Hence the illusion that law is based on the will, and indeed on the will divorced from its real basis —on free will. (GI, p. 187)

In this quotation, two theoretical positions are clearly stated. One is the instrumental conception of the State: the State is nothing more than one of the instruments through which the dominant class exerts its power. The other is the permanence, in Marx's discourse, of the rejection of mediation.

This conception is reinforced in some passages of the Manifesto, where a very simplistic conception of political power, but one coherent with the previous discourse, is set forth: "Political power in its true sense is the organized power of one class for oppressing another" (MCP, p. 20). The devaluation of the political, and with it of "political power" was completed, then, well before the mature writings. 
Marx criticism of politics is summarized and presented in political (as opposed to philosophical) terms in an article published in 1844: ${ }^{18}$

Short of abolishing itself, the state cannot abolish the contradiction between the role and good will of the administration on the one hand, and its means and power on the other. The state is based on this contradiction. It is based on the contradiction between public and private life, on the contradiction between universal interests and particular interests. (CNKP, p. 106; MEGA, I.2, p. 456)

In political terms, then, the State (and with it politics) is based, for Marx, on a clear-cut contradiction between particular and universal interests. The source of this contradiction is the fact of the alienated individual. The solution to alienation is, of course, the community; actual politics is, in the end, an utterly irrelevant activity. ${ }^{19}$

\section{Marx's Positive Conception of Politics}

In order to understand Marx's negative conception of politics, it is important to recognize that something is missing from the previous analysis. The "negative" conception only makes sense if one has a clear notion of the "positive" conception implicit in Marx's descriptions and criticisms of actual politics. To understand Marx's complete conception of politics, then, it

18 "Critical Marginal Notes on the Article 'The King of Prussia and Social Reform. By a Prussian" "; see the reference at the end.

19 "The more developed and general the political understanding of a people is, the more the proletariat - at least in the beginning of the movementwastes its strength in stupid, useless, blood-drenched uprisings. Because it thinks in political forms, it sees the basis of all evils in the will and all means to their melioration in power and the overthrow of a particular form of state. Proof: the initial outbursts of the French proletariat. The workers in Lyons believed they were following only political goals, that they were only soldiers of the Republic, while in truth they were soldiers of Socialism. Thus their political understanding obscured for them the root of social distress, thus it falsified their insight into their actual purpose, and thus their political understanding deceived their social instinct" (CNKP, p. 112). 
is necessary to read his writings in a particular way. One has to be aware that Marx's rhetoric includes both the negative and positive conceptions in the same texts and even in the same paragraph. In every paragraph in which politics or the State is discussed, Marx uses his positive conception as an implicit standard for judging — and criticizing - actual politics and the State. It is this rhetoric strategy which has produced a partial and unbalanced understanding of how Marx uses the concept of politics.

Marx's positive conception of politics is introduced through the notion of democracy. ${ }^{20}$ Democracy, for Marx, is the culmination of all forms of government. In his words:

In a democracy the abstract state has ceased to be the dominant moment. The conflict between monarchy and republic still remains a conflict within the framework of the abstract state. The political republic is a democracy within the abstract form of the state. Hence the abstract political form of democracy is the republic; here, however, it ceases to be merely a political constitution. (CHDS, p. 89; MEGA, I.2, p. 32)

The path, then, goes from monarchy to a republic to a democracy, ${ }^{21}$ but not any kind of democracy. As should be expected, Marx presents a radical conception of democracy. Democracy, at this early stage of Marx's thought, is conceived as the truth of all forms of the State (CHDS, p. 89) or, in other words, as the rational form of politics. The truth-rationality of democracy consists in the lack of separation:

In all forms of the state other than democracy the state, the law, the constitution, is dominant, but without really dominating, i.e., without materially penetrating the content of all the non-political spheres. In a democracy the constitution, the law, i.e., the political state is itself only a self-determination of the people and a 2003.

${ }^{20}$ See, on this respect, O'Malley 1994, Avinieri 1968, Chap. 1, and Salazar

${ }^{21}$ See O’Malley 1994, pp. xx-xxi. 
determinate content of the people. Moreover, it goes without saying that all forms of the state have democracy for their truth and that they are untrue to the extent that they are not democracy. (CHDS, pp. 88-89; MEGA, I.2, p. 32)

At this point of his writings Marx expressed, through the concept of democracy, two main concerns: the cancellation of separation (or mediation) between individuals and the "materialist" emphasis on the participation of "real" people versus "abstract" individuals. As Marx ${ }^{22}$ puts it: "Democracy is the solution to the riddle of every constitution" (CHDS, p. 87). What is the "riddle" of every constitution? The cancellation of domination. Why is democracy the solution to the riddle of constitutions? Marx's answer is, again, clear:

In it [democracy] we find the constitution founded on its true ground: real human beings and the real people: not merely implicitly and in essence, but in existence and in reality. The constitution is thus posited as the people's own creation. The constitution is in appearance what it is in reality: the free creation of man. (CHDS, p. 87; MEGA, I.2, p. 31)

Democracy means here self-rule, and implies the capacity of human beings for autonomous action. Once autonomy is deemed as a feasible "mode" of human action, there is no longer any need for institutions that control, direct and coerce human activity. This means that the only good politics is the politics in which neither rule nor domination exist, only community.

This idea is evident in the "Critical Marginal Notes on the Article 'The King of Prussia and Social Reform"', where Marx linked the notions of community and politics:

But the community from which the worker is isolated is a community the real character and scope of which is quite different from that of the political community. The community from which the

22 “Die Demokratie ist das Aufgelöste Räthsel aller Verfassungen” (MEGA, p. 31). 
worker is isolated by his own labor is life itself, physical and mental life, human morality, human activity, human enjoyment, human nature. Human nature is the true community of men. (CNKP, p. 113; MEGA, I.2, p. 462)

The objective of the cancellation of domination is exposed in The German Ideology:

Further, it follows that every class which is struggling for mastery, even when its domination, as is the case with the proletariat, postulates the abolition of the old form of society in its entirety and of domination itself, must first conquer for itself political power in order to represent its interest in turn as the general interest, which in the first moment is forced to do. (GI, p. 161)

Democracy, in the end, is the "truth" of "all forms of the state" and "they [the forms of the state] are untrue to the extent that they are not democracy" (CHDS, p. 89; MEGA, I.2, p. 32).

To summarize, for Marx politics consists, really and truly, in the participation in a community of free and emancipated human beings, in which all alienation and, therefore, all domination is cancelled. The concept of "democracy", under this logic, has to loose in the final instance its second part ("cratos"), in order to maintain the full autonomy of everyone; we are left, then, only with a "demos". ${ }^{23}$ This shows, then, that there is no break between the young and the old Marx concerning the "solution" to human problems but rather a clear continuity in Marx thought: true democracy is communism. ${ }^{24}$ This means,

${ }^{23}$ Which Marx himself recognizes: "Democracy is the truth of monarchy; monarchy is not the truth of democracy. [...] Monarchy cannot be explained in its own terms; democracy can be so explained. In democracy no moment acquires a meaning other than what is proper to it. Each is really only a moment of the demos as a whole" (CHDS p. 87).

${ }^{24}$ As Shlomo Avinieri maintains "A close inspection of what Marx really said in the Critique about the nature of 'true democracy' makes it extremely difficult to sustain this notion [that 'Marx's political solution at that time was democratic, and only later did communism appear in his writings']. It can be shown clearly that what Marx terms 'democracy' is not fundamentally 
finally, that in Marx's writings a positive conception of true politics as community politics exists.

In the EPM, Marx abandons democracy in his positive sense and consistently starts using "communism" to refer to the best social setting. However, the similarities between the notions of "true democracy" and "communism" are evident, as the following quotation shows:

Communism is the positive supersession of private property as human self-estrangement, and hence the true appropriation of the human essence through and for man; it is the complete restoration of man to himself as a social, i.e. human being [...]. This communism, as fully developed naturalism, equals humanism, and as fully developed humanism equals naturalism; it is the genuine resolution of the conflict between man and nature, and between man and man, the true resolution of the conflict between existence and being, between objectification and self-affirmation, between freedom and necessity, between individual and species. It is the solution to the riddle of history and knows itself to be the solution. (EPM, p. 348) $)^{25}$

Just as in the Critique of Hegel's Doctrine of the State democracy is the solution to the riddle of every constitution, communism, in the Manuscripts of 1844, is the solution to the riddle of history. This does not mean, as is widely believed, that the older Marx "abandoned politics" as a way of attaining liberation; on the contrary, it means that both the young

different from what he will later call 'communism', and that in any case this 'democracy' is based on 'man's communist essence'" (Avinieri 1968, p. 34). Furthermore: "The universalistic nature of the proletariat does not disappear in Marx's later writings, when his discussion concentrates mainly on the historical causes of the emergence of the proletariat. What was at the outset a philosophical hypothesis in Kapital is a detailed study of the economic aspects of the process annunciated by Marx in his Economic-Philosophical Manuscripts: what was philosophically postulated in 1844 is now verified and vindicated by an analysis of capitalist economic activity undertaken with the tools of classical political economy" (Avinieri 1968, p. 118).

${ }^{25}$ In German, the last sentence of the quotation reads: "Er [Der Communismus] ist das Aufgelöste Räthsel der Geschichte und weiß sich als diese Lösung" (MEGA, p. 389). 
and the old Marx held the same positive conception of politics as community life without domination. "True democracy" is "communism". The older Marx simply realized that there was no sense in including the suffix cratos in a proposal that only had place for a demos, for a community, and not for a government. However, this is not a rejection of politics tout court, but only a rejection of the politics of domination in favor of the politics of community or, in Marx's vocabulary, true politics.

\section{Conclusion. On an Apolitical Conception of Politics}

Marx is, undoubtedly, one of the great social theorists of modernity and no amount of criticism can deny his many deep insights into modern society. Marx is a classic of social thought and should be read as any other classic, time and time again, because he managed to produce a master interpretation of his time and a number of categories and insights still relevant today (Bobbio 1976). Marx's genius and greatness, however, should not blind us to the serious inconsistencies in his thought. The criticism of Marx is important due to his enormous influence in contemporary social thought and practice. His many dubious statements have been noted and attacked for a long time, but attention has been paid mainly to his economic theory, his interpretation of history and his predictions concerning the future of capitalism. Today, few economists present themselves as Marxists; historical materialism is only one among many schools of historical research, and few now believe that capitalism is on the way to destruction or that some kind of communist society will follow. Furthermore, probably only a few academics read Marx's works nowadays. His legacy, however, is alive and well when it comes to the criticism of the status quo and as a source of radical political imagination. It is indeed paradoxical that today Marx's influence is felt precisely on the subject to which he paid least attention. Since we may expect this to be the case for many years to come, we ought to have a clear understanding of concepts and notions that for him and for many interpreters and followers were of little importance and, therefore, received 
little attention, but that deal with basic human activities and institutions: politics and the State.

As was stated earlier, this exercise only makes sense if one considers the enormous influence that the positive Marxist conception of politics has had, and still has, in the political imagination of the world, particularly in the conception of politics held by many on the left, from violent revolutionaries to peaceful members of NGOs, to neo-anarchists. The political practice of the left has been characterized, in many cases, by the odd combination of the crudest kind of political realism, of an unprincipled kind that would have surprised even Machiavelli, ${ }^{26}$ with a radical conception of a non-political society in which domination is simply unnecessary. This combination has had dire effects both on the understanding of politics and on political practice, and the main reason is easy to perceive. Some general conceptions of politics, like classical liberalism, offer partial solutions to the ills of the world; others, like conservatism, maintain that no new solution would work; and yet others, like fascism, propose that only complete unity under authoritarian rule can function. However, all these conceptions have one element in common: some kind of rule or domination is unavoidable. By the same token, even traditional conceptions of politics constructed around the notions of community and participation, such as those of Aristotle, Rousseau and many republican authors, maintain the same basic element: politics always includes some kind of domination (of institutionalized domination), even under some form of self-rule.

What Marxism proposes is something new: the use of the worst kind of domination, that is, uncontrolled domination, ${ }^{27}$ to end all domination. This proposal depends, as we have seen, on the "positive" conception of politics held by the young Marx. Where does this conception come from? Allan Megill has recently provided a partial answer. For Megill, Marx rejected politics (what I called here his "negative" conception) because

${ }^{26}$ One just has to think of Trotsky, Lenin, Stalin, Castro or Mao, for understanding the importance of this version of politics.

${ }^{27}$ As Marx clearly states in the Manifesto; see MCP, p. 19. 
he came to realize two things: politics lacks an immanent rationality, and science, not philosophy, would show us the way to solve our problems (Megill 2002, p. 58). However, as Megill acknowledges, "Marx's conception of politics [...] always remained indentured to the criteria of universality, necessity and predictivity that came to him from philosophy. In this sense, Marx never 'left' philosophy although he certainly attempted to do so." (Megill 2002, p. 62)

Marx's "positive" conception of politics, then, comes strictly from the universal criteria of philosophy. This, however, is only part of the picture. The other part comes also from philosophy, but from "content", not "criteria", particularly from the two unwarranted assumptions discussed in the first section of this paper: the assumption that the basic human problem was alienation, and the assumption that the solution to that problem has to be radical and has to achieve complete emancipation or, in Marx's particular sense, freedom.

What we have in front is an utterly idealist and inconsistent conception of how politics works. Politics, as John Dunn maintains in his recent book on the subject, has always been thought of as involving some kind of domination. For Dunn, the "least controversial feature" of Aristotle's "viewpoint today"

is his presumption that politics (both what he [Aristotle] called 'politics' and, anachronistically, what we ourselves call 'politics') is inherently concerned with rule, the regular exercise of ultimately coercive authority by some human beings over others. (Dunn 2000, p. 15)

Either the notion of politics involves, to some degree, the notions of rule and/or domination, or it simply does not refer to politics. To call politics what is devoid of domination is nothing more that an oxymoron. In Marx's case it is precisely this oxymoron what is used to criticize real politics as false politics and, therefore, as the basis of his criticism of actual politics.

Actual, real politics is - since it involves domination-false politics and, consequently, should not be taken seriously. It 
should only be considered as an instrument of domination; either of bourgeois or capitalist domination or, in the revolutionary sense, of proletarian domination. Democratic politics, on the other hand, has as its main trait the absolute lack of domination. The key to understand Marx's conception of politics, then, is the criticism of rule and domination. The basic problem with this conception is that politics cannot be conceived without the notion of domination. This oxymoronic conception has dreadful consequences for the understanding of politics and for the evaluation of both democracy and freedom.

Marx's incoherent conception of politics carries two main consequences. First, the conception of the State as simply an instrument of the dominant class has very limited explanatory and descriptive powers, since the State is in effect a multi-class institution, guided by different and often conflicting interests.

Second, the conception of politics as simply an instrument of domination hinders the possibility of appreciating the positive traits of real politics such as the capacity of political negotiation to cancel violence and war, to empower disadvantaged sectors of society, to establish consensus between groups with disparate or conflicting interests, not to mention the fact that only the State, through political action, can produce the necessary levels of safety, stability and peace for the development of civilization.

This devaluation is the direct outcome of the dialectic interplay of three notions: alienation, emancipation and speciesbeing. These notions do not come from a deep analysis of social history or from a careful description of social experience. They come from the work of another philosopher. As is well known, Feuerbach's criticism of mankind's religious alienation is the basis for Marx's notions of alienation and "species-being" (Avinieri 1968, Chap. 1, and Salazar 2003). It is also well known that, in the end, it is Aristotle's and Hegel's depictions of human beings as eminently "community" beings and of community as the preeminent actor of politics, ${ }^{28}$ what established the basis of Marx's political thought. The basis of Marx criticism of politics is, then, twofold. On the one hand, an idealized version of Greek politi-

${ }^{28}$ See, on this subject, Gilbert 1991, pp. 168-176. 
cal practice and, on the other, an utterly moralistic and strictly theoretical (that is, without any empirical control) conception of how human beings, in effect, are. That is, regardless Marx's self-conception, his criticism of actual politics is as idealist as Feuerbach's criticism of religion.

It is true that Marx was not an empiricist, and that his conception of truth is closer to that of the rationalist. As Ian Shapiro maintains, Marx had a "deductive view" of science and "he had not the slightest interest in fallibilism or empirical tests of his claims" (Shapiro 2003, p. 74). This, however, should not stop us from criticizing his theses, particularly in view of their consequences. Marx simply rejects as irrelevant for the objective of emancipation a crucial practice in human history, politics, advocates its cancellation and, furthermore, proposes a completely different conception of it based exclusively on a couple of dogmatic and largely implausible philosophical stipulations. Why are they implausible? The best answer was provided by Hobbes, himself great critic of Aristotle. On Hobbes' view, conflict among human beings is not the outcome of a particular institutional setting, but part of the human condition, which is the result of human beings' desire to survive in a situation of permanent scarcity. Conflict, therefore, can only be tamed, controlled and diminish, not cancelled (or "sublated"). ${ }^{29}$ Is Hobbes" position true and Marx's false? No, since they cannot be subject to falsification. The correct question has to be whether one is more or less plausible than the other as a way of understanding society, that is, of explaining and, to a degree, predicting behavior. Hobbes ${ }^{30}$ solved this problem by asking the reader to consider his or her own experience: when you travel, do you leave your house wide open? Or, do you travel without some form of protection? Nowadays we could ask, for example: Would you leave your car parked on the street with the door open and the keys in the ignition? The answer is not automatically no. In some parts of the world people may actually leave the door unlocked or, at least, they are not constantly worried

${ }^{29}$ See Leviathan, Chap. XIII.

${ }^{30}$ Cf. Leviathan, Chaps. VI, X, XIII. 
about their car being stolen. Where can one find this happy state of affairs? Precisely there where the State is stronger and where politics is a stable and well organized activity. Where is insecurity greater? Precisely there where a State is lacking. ${ }^{31}$

The typical Marxist thesis is that security problems, as well as many other social ills, are caused by unequal social conditions which are ultimately caused by the alienation produced by the State and the Market. The solution is the cancellation of all states of affairs that produce or promote alienation, with the objective of achieving liberation. The problem with this solution, and what makes it radically implausible, is that it only works inside a metaphysical and teleological philosophy of history. Furthermore, it is based on an absolute ideal: reality will always fall short of such ideal. In Marx's argument, then, a philosophical stipulation - human beings as "species-being"functions as the basis of criticism of what is a highly successful human practice, namely, politics. The force of the argument comes not from its epistemic cogency, but from its rhetoric force, particularly from the moralistic content of the notion of "species-being": community versus individual and altruism versus egoism. Rhetoric, however, is not enough for the clear understanding of human practices. The Marxist conception is, then, a poor instrument for the understanding of both political causality and political capacity.

This conception of politics has also had appalling consequences for the understanding both of democracy - the foremost form of government of contemporary times - and freedom - the principal value of modern societies.

As we saw, for the young Marx true or real politics is an idealization of Greek politics: a community of free men. True and real politics means for Marx - in general- community life that has no institutional mediation. "Democracy", therefore, means nothing more than the participation of all citizens in public life. The combination of an utterly negative conception

${ }^{31}$ Africa is a great example, but consider also Latin America, in particular places like Colombia, Brazil or Mexico, where the State simply cannot go into some parts of the territory. 
of real politics with a utopian conception of democracy - of positive politics - produces a simplistic conception of democracy as communism. That is, democracy as the total absence of domination, as the pure - unmediated and unfettered - participation of citizens in public affairs. This is clear in Marx's understanding of freedom and the State presented in his Critique of the Gotha Program: "Freedom consists in converting the state from an organ superimposed upon society into one completely subordinated to it, and today, too, the forms of state are more free or less free to the extent that they restrict the "freedom of the state" "(CGP, p. 537).

The idea is clear but simplistic. If freedom means the cancellation of mediation between human beings, then the State (or any means of bureaucratic mediation) has to disappear. What Marx proposes is political participation without mediation, without the institutional structures that have proved to be indispensable for the efficient and stable conduction of public affairs. This anti-institutional conception of government is presented in Marx's comments of the Paris Commune of 1871, which appear in section III of The Civil War in France. There, Marx defends the Commune efforts to develop a "working" and not "representative" government, which would conflate the executive and legislative, and in which the people themselves would execute the functions of the "corrupt" bureaucracy and army.

This conception of democracy has had a great impact on the political imagination of many social critics and activists (beginning, of course, with Lenin). Regardless of its incoherence, it has been the basis of the rejection of "formal" or "bourgeois" democracy, the defense of many strictly theoretical "forms" of democracy, ranging from "substantive" to "deliberative", as well as the recent advocacy of diverse forms of communitarianism. The common denominator of all these philosophical proposals is an obsession with the cancellation of domination and with the separation (or individuality), which are Marx's basic arguments for criticizing actual politics and for advocating true democracy. The element that gives such a moralist and idealist 
conception of democracy its charm is, in effect, the aspiration to cancel all domination or, in other words, the aspiration to liberation. Its principal problem, however, is that it promises a state of affairs that can not be fulfilled, that is, strictly speaking, utopian.

The worst consequence of combining a utopian and antipolitical conception of politics with a crudely realist one is the criticism and devaluation of individual freedoms. Marx's position on this problem is well known. Political liberation in the modern State is incomplete liberation. ${ }^{32}$ Liberal liberty is, therefore, incomplete liberty, liberty of a "separated" individual, and not sufficient for an authentic human being. Marx is clear on this point:

This fact [modern bourgeois freedom] appears even more curious when we observe that citizenship, the political community, is reduced by the political emancipators to a mere means for the conservation of these so-called rights of man and that the citizen is therefore proclaimed the servant of egoistic man; that the sphere in which man behaves as a communal being [Gemeinwesen] is degraded to a level below the sphere in which he behaves as a partial being, and finally that it is man as bourgeois, i.e. as a member of civil society, and not man as citizen who is taken as the real and authentic man. (JQ, p. 231; MEGA, I.2, p. 159)

Paragraphs like this one are the basis of the liberal interpretation that makes Marx a critic of the very notion of human rights. This interpretation has been challenged recently using both Marx's writings and an interpretation of Marx "real" intentions. Marx clearly saw modern political emancipation as progress, even if partial and incomplete. ${ }^{33}$ This has prompted contemporary interpreters to maintain that Marx had a manifest "commonality" with liberalism, even if he failed to "spell out"

${ }^{32}$ See JQ, p. 218.

33 "Political emancipation is certainly a big step forward. It may not be the last form of general human emancipation, but it is the last form of human emancipation within the prevailing scheme of things. Needless to say, we are speaking of real, practical emancipation" (JQ, p. 221). 
such commonality (Gilbert 1991, p. 189). Under this interpretation, Marx is a post-liberal thinker that would never have approved of the totalitarian regimes erected in his name. Marx himself, however, gives his recent supporters a very difficult time with paragraphs like this one:

We have seen above that the first step in the revolution by the working class is to raise the proletariat to the position of ruling class, to win the battle of democracy. The proletariat will use its political supremacy to wrest, by degrees, all capital from the bourgeoisie, to centralize all instruments of production in the hands of the State, i.e., of the proletariat organized as the ruling class; and to increase the total of productive forces as rapidly as possible. Of course, in the beginning, this cannot be effected except by means of despotic inroads on the rights of property, and on the conditions of bourgeois production ${ }^{34}$ by means of measures, therefore, which appear economically insufficient and untenable, but which, in the course of the movement, outstrip themselves, necessitate further inroads upon the old social orders, and are unavoidable as a means of entirely revolutionizing the mode of production. (MCP, p. 19)

This clear advocacy of despotism consistent with the arguments proposed in JQ. Only a wildly optimistic conception of politics as community self-rule, combined with a metaphysical conception of emancipation can deem modern individual rights, and the conception of freedom which supports them, as "bourgeois", limited or partial and, therefore, as expandable or as nothing more than a way to masquerade the naked exercise of power.

$* * *$

In this paper I have shown that two different and opposed conceptions of politics can be found in Marx's early writings. On the one hand, the view generally recognized by the majority of interpreters: a negative, instrumental and realist conception that

${ }^{34}$ In the original: "despotischer Eingriffe in das Eigentumsrecht und die Bürgerlichen Produktionverhältnisse” (Engels and Marx 1955, p. 246). 
construes politics as an instrument either of domination or of revolution. On the other hand, a positive conception of politics that sees it as unfettered participation in public affairs, which the young Marx called "democracy". The criterion for distinguishing between them is the presence or absence of domination. Actual politics is negative because it involves domination, while democratic politics is true politics because it has no place for domination. The combination of these two conceptions has produced an odd vision of politics with a deep and enduring influence on the way that many sectors of the left conceive political practice. It is a vision that combines a crude version of political realism, devoid of any political principles and in which the only function left for politics is that of being an instrument to achieve domination, with a utopian and hopeful conception of politics as a situation of full participation, full equality and absolutely no-domination.

These two radical conceptions of politics are the result of three assumptions made by Marx. These assumptions are the concepts, which mirror each other, of "alienation" and "emancipation", and the notion of "species-being". The source of Marx's conception of politics, then, is not - as would be expected of a materialist author - experience or a careful description of political history. The source is to be found in a group of philosophical notions, which function as stipulations concerning the human condition. Marx's complete (so to speak) conception of politics, then, is a moralistic and idealistic one, and does not take into account experience or history. History is important for his positive conception, but only Marx's teleological and metaphysical version of it.

Marx's conception of politics has had negative consequences on three subjects: the understanding and evaluation of politics, democracy and freedom. It impedes a correct understanding of the real positive traits of politics such as its capacity to empower societies, to solve conflicts through negotiation, to produce institutions that provide stability to social life and, most importantly, to guarantee security. Marx's limited conception of politics produces, also, a utopian conception of democracy that 
highlights participation and emancipation without dealing with the problems inherent in any form of government. The worst consequences are to be found in the discussion of freedom. Marx's fixation with alienation and emancipation makes the liberal conception of political freedom an incomplete one, and the combination of his negative and positive conception makes individual political freedom just a masquerade of domination; it is false and incomplete freedom. The outcome is a devaluation of human rights - seen as simply bourgeois, not humanand the defense of any mean necessary to achieve liberation, the imprecise stipulation he uncritically set as the main human objective.

\section{REFERENCES*}

English translations of Marx's texts

Marx, K., 1996, Later Political Writings, Cambridge University Press, Cambridge:

- Manifesto of the Communist Party (1848) [MCP] 1994, Early Political Writings, Cambridge University Press, Cambridge:

- "Critical Marginal Notes on "The King of Prussia and Social Reform. By a Prussian"” (1844) [CNKP]

Benton, Pelican Books, London:

- Critique of Hegel's Doctrine of the State (1843) [CHSDS]

- "On the Jewish Question" (1843) [JQ]

- "A Contribution to the Critique of Hegel's Philosophy of Right. Introduction" (1843-1844) [ICH]

- Economic and Philosophical Manuscripts (1844) [EPM]

* I have relied on available English translations which are, in general, of a good quality. However, I have included references to the original in German for paragraphs deemed crucial for this paper. 
Marx, K. and F. Engels, 1978, The Marx-Engels Reader, 2nd ed., ed. by Robert C. Tucker, W.W. Norton, New York/London:

- The German Ideology, part I (1845-1846) [GI]

- Critique of the Gotha Program (1891) [CGP]

\section{German versions}

Engels, F. and K. Marx, 1955, Das Kommunistische Manifest, Schriften aus dem Karl-Marx-Haus, Trier.

Marx, K. and F. Engels, 1974, Gesamtausgabe, 2nd ed., Dietz Verlag, Berlin (1927). [MEGA]

\section{Secondary Sources}

Avinieri, S., 1968, The Social and Political Thought of Karl Marx, Cambridge University Press, Cambridge.

Bobbio, N., 1976, Which Socialism?, University of Minnesota Press, Minneapolis.

Carver, T., 1998, The Postmodern Marx, The Pennsylvania University Press, University Park.

Dunn, J., 2000, The Cunning of Unreason, Basic Books, New York.

Elster, J., 1986, An Introduction to Karl Marx, Cambridge University Press, Cambridge.

Geuss, R., 2001, History and Illusion in Politics, Cambridge University Press, Cambridge.

_ 1998, "Freiheit im Liberalismus und bei Marx", in J. NidaRümelin and W. Vossenkuhl (eds.), Ethische und politische Freiheit, Walter de Gruyter, Berlin/New York.

Gilbert, A., 1991, "Political Philosophy: Marx and Radical Democracy", in T. Carver (ed.), The Cambridge Companion to Marx, Cambridge University Press, Cambridge.

Harding, N., 1992, “The Marxist-Leninist Detour”, in J. Dunn (ed.), Democracy. The Unfinished Journey, Oxford University Press, Oxford.

Hegel, G.W.F., 1952 (1821), Philosophy of Right, tr. T.M. Knox, Clarendon Press, Oxford.

Megill, A., 2002, Karl Marx. The Burden of Reason, Rowman and Littlefield, New York.

Miliband, R., 1977, Marxism and Politics, Oxford University Press, Oxford.

O’Malley, J., 1994, "Editor's Introduction" to K. Marx, Early Political Writings, Cambridge University Press, Cambridge. 
Salazar, L., 2003, "El joven Marx y la crisis de la filosofía política", in Signos Filosóficos, no. 9, pp. 191-226.

Shapiro, I., 2003, The Moral Foundations of Politics, Yale University Press, New Haven.

Wood, A., 1981, Karl Marx, Routledge and Kegan Paul, London.

Received January 23, 2003; revised June 9, 2004; accepted July 7, 2004. 